$9-15-2011$

\title{
Design and Synthesis of A Biotinylated Probe of COX-2 Inhibitor Nimesulide Analog JCC76
}

\author{
Bo Zhong \\ Cleveland State University \\ Rati Lama \\ Cleveland State University \\ Kerri M. Smith \\ Cleveland State University \\ Yan Xu \\ Cleveland State University, y.xu@csuohio.edu \\ Bin Su \\ Cleveland State University, B.SU@csuohio.edu
}

Follow this and additional works at: https://engagedscholarship.csuohio.edu/scichem_facpub

Part of the Chemistry Commons

How does access to this work benefit you? Let us know!

\section{Recommended Citation}

Zhong, Bo; Lama, Rati; Smith, Kerri M.; Xu, Yan; and Su, Bin, "Design and Synthesis of A Biotinylated Probe of COX-2 Inhibitor Nimesulide Analog JCC76" (2011). Chemistry Faculty Publications. 174. https://engagedscholarship.csuohio.edu/scichem_facpub/174

This Article is brought to you for free and open access by the Chemistry Department at EngagedScholarship@CSU. It has been accepted for inclusion in Chemistry Faculty Publications by an authorized administrator of EngagedScholarship@CSU. For more information, please contact library.es@csuohio.edu. 


\title{
Design and synthesis of a biotinylated probe of COX-2 inhibitor nimesulide analog JCC76
}

\author{
Bo Zhong , Rati Lama , Kerri M. Smith , Yan Xu , Bin Su
}

Numerous studies have demonstrated overexpression of cyclo oxygenase 2 (COX 2) in solid malignancies including breast, pros tate, colon, pancreas, nonsmall cell lung, bladder, and endo metrium. ${ }^{1-5}$ Prostaglandin $2\left(\mathrm{PGE}_{2}\right)$, the product of COX 2, pro motes tumor invasiveness, angiogenesis, and progression in various cancers. ${ }^{1,4,5}$ It is therefore reasonable to conclude that inhibition of COX 2 would arrest carcinogenesis and thus, (1) prevent cancer development and (2) regress cancer once developed. Corresponding to these observations and theory, epidemiological, clinical, and pre clinical studies provide compelling evidence that the use of COX 2 selective inhibitors may reduce the incidence of mammary cancer and colorectal cancer. ${ }^{6-9}$ Theoretically, COX 2 inhibitors achieve all the anti cancer or cancer preventive activity by targeting COX 2. However, these small molecules may also block other cellular machineries to affect the cancer cell function, which may lead to cell growth inhibition, apoptosis or necrosis. With the extensive studies of COX 2 inhibitors about their anti cancer or cancer pre vention activity, molecular targets of the drugs beyond COX 2 seems play a very important role for their antineoplastic activity. Many researchers even suggested that COX independent effects might be fully responsible for the anti cancer properties of some COX 2 inhibitors. ${ }^{10,11}$ The phenomenon is more like an off target ef fect, which also underscores the needs to explore targets beyond COX 2, especially in view of emerging toxicity of the COX 2 inhib itors. Developing nonCOX 2 inhibitory analogs as new anti cancer drug based on COX 2 inhibitors as lead compound is feasible and practicable. In fact, this principle has been successfully applied in the discovery of some new anti cancer drugs. For instance, COX 2 inhibitor Celecoxib weakly inhibits PDK 1 kinase in prostate cancer cells. It has been used as a molecular scaffold to develop more po tent PDK 1 inhibitors (no COX 2 inhibitory activity) which block PI3 K/AKt pathway. The generated new analog, such as OSU 03012 is 20 fold more active than Celecoxib to inhibit tumor cell proliferation and to induce cell apoptosis, which is currently in a phase I clinical trial. ${ }^{12,13}$ Nimesulide ( 4 nitro 2 phenoxymethane sulfoanilide) is a nonsteroidal anti inflammatory drug with a pref erential COX 2 inhibitory activity and is available in some Asian and European countries since 1985. Studies suggest that nimesulide could induce apoptosis in liver and lung cancer cells; it also suppressed the development of 2 amino 1 methyl 6 phenylimi dazo[4,5 b]pyridine (PhIP) induced mammary gland carcinogene sis in rats. ${ }^{14-17}$ NonCOX 2 active nimesulide derivatives have been synthesized. Some analogs were much more active than nimesulide in suppressing breast cancer cell growth. ${ }^{18}$ Interest ingly, the most potent analog JCC76 was selectively potent in Her2 overexpressed breast cancer cells. ${ }^{19,20}$ Both in vitro and in vivo anticancer properties of JCC76 make it a potential new drug candidate or drug lead for Her2 overexpressed breast cancer.

To rational design more potent analogs of JCC76 based on its binding pocket and optimize the structure activity relationship (SAR), it is a prerequisite to identify the specific molecular target(s) of JCC76. Although JCC76 exhibited good selectivity to Her2 over expressed breast cancer cells, it did not show any significant block 


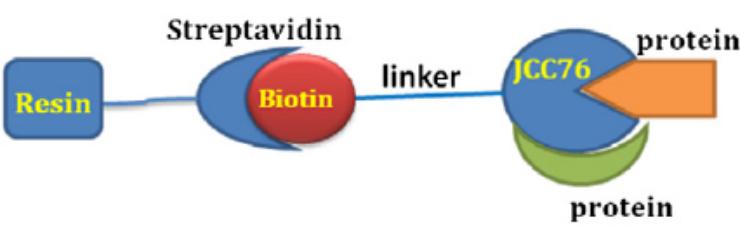

Figure 1. JCC76 biotinylated probe design.

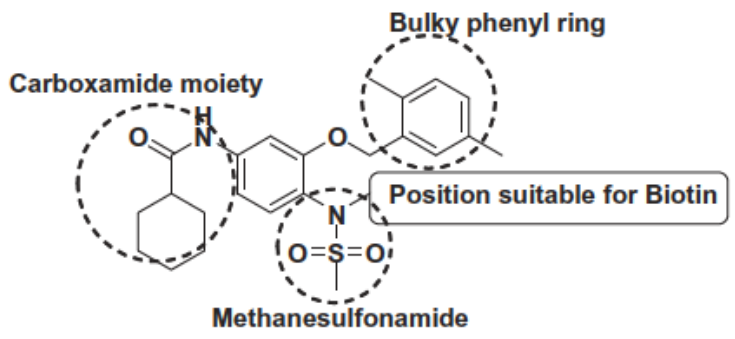

Figure 2. JCC76 structure analysis.

ing effects on the well documented Her2 downstream kinases. ${ }^{19,20}$ It is difficult to elucidate the molecular targets of JCC76 by check ing the signal transduction net in Her2 overexpressed breast can cer cells. In an effort to identify the bio molecule(s) that bind to JCC76, we planned to use biotin streptavidin affinity purification. For this purpose, biotinylated derivative of JCC76 with consider able bioactivity should be designed and synthesized. Generally, a biotinylated linker can be incorporated at the suitable position of JCC76, so that the biological activity of the small molecule can be conserved. Moreover, a linker between small molecule and biotin should have appropriate length in order to provide enough space for biotin to interact with streptavidin (Fig. 1).

The previous structure activity analysis indicated that the inhi bition of breast cancer cell growth by nimesulide derivatives re quires a hydrophobic group substituted bulky phenyl ring, a methanesulfonamide and a hydrophobic carboxamide moiety. ${ }^{18}$ Those three moieties might not be suitable for incorporation of biotinylated linker. $N$ methyl group on the sulfonamide group is the only position feasible for the introduction of biotin (Fig. 2).

Replacement of $N$ methyl group with hydrogen or alkyl chains of different length generated a series of novel derivatives. The syn thetic approach used is shown in Scheme 1. The key intermediate 5 was prepared according to the procedure previously used for syn thesis of JCC76. ${ }^{18}$ The starting material 1 was treated with 2,5 dim ethylbenzylbromide in the presence of potassium carbonate to afford compound 2, followed by mesylation and hydrolysis to gen erate compound 3. Instead of $N$ methylation of sulfonamide group, compound 3 was directly reduced in the presence of $\mathrm{Zn} / \mathrm{FeCl}_{3}$ to generate substituted aniline 4. Coupling with cyclohexanecarbonyl<smiles>Cc1ccc(C)c(COc2cc([N+](=O)[O-])ccc2NS(C)(=O)=O)c1</smiles><smiles>CCc1ccc(C)c(COc2cc(N)ccc2N(C)S(=O)(=O)O)c1</smiles>
4 5

$6 \mathrm{a}, \mathrm{R}=\mathrm{n}-\mathrm{C}_{6} \mathrm{H}_{13}$ $6 b, \mathrm{R}=\left(\mathrm{CH}_{2}\right)_{2} \mathrm{O}\left(\mathrm{CH}_{2}\right)_{2} \mathrm{OCH}_{3}$ $6 \mathrm{c}, \mathrm{R}=\left(\mathrm{CH}_{2}\right)_{6} \mathrm{OH}$<smiles>Cc1ccc(C)c(COc2cc(NC(=O)C(C)C)ccc2N(CCCCCCCN)S(C)(=O)=O)c1</smiles>

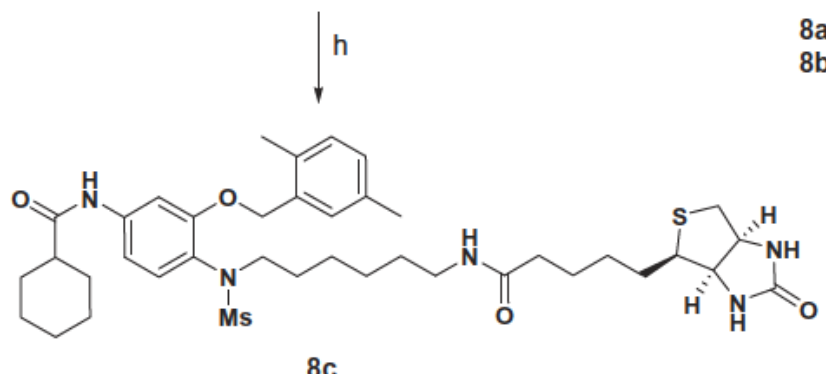

$8 \mathrm{a}, \mathrm{R}=\mathrm{n}-\mathrm{C}_{5} \mathrm{H}_{11}$

$8 c$

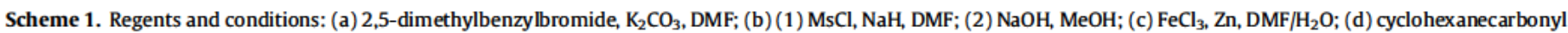

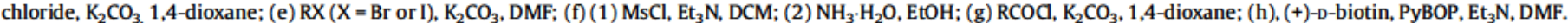


Table 1

$\mathrm{IC}_{50}$ of inhibition of SKBR-3 breast cancer cells growth by JCC76 probes

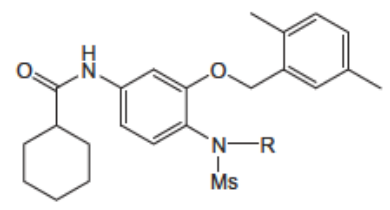

\begin{tabular}{|c|c|c|}
\hline Compound & $\mathbf{R}$ & Inhibition of SKBR-3 cell growth $\left(\mathrm{IC}_{50} \mu \mathrm{M}\right)$ \\
\hline JCC76 & Me & $3.43 \pm 1.57$ \\
\hline $6 \mathbf{a}$ & & $81.68 \pm 31.18$ \\
\hline $8 a$ & & $6.00 \pm 2.52$ \\
\hline $8 \mathbf{b}$ & & $45.28 \pm 12.47$ \\
\hline $8 c$ & & $2.21 \pm 0.78$ \\
\hline
\end{tabular}

SKBR-3 cells were treated with indicated compounds at various concentrations by triplicates for $48 \mathrm{~h}$ and cell viability was measured by MTT assay. ${ }^{22}$

chloride afforded $5 . N$ alkylation of sulfonamide group with alkyl bromide/iodide in the presence of potassium carbonate yielded 6a c. Conversion of hydroxyl group in $\mathbf{6 c}$ to amino group followed by coupling with alkyl or aromatic carbonyl chloride generated 8a b. ${ }^{21}$

The anti proliferation effect of compounds $5, \mathbf{6 a} \mathbf{b}$, and $8 \mathbf{a} \mathbf{b}$ was evaluated against breast cancer cell line SKBR 3. The results are summarized in Table 1 . It can be seen that alkyl group on the nitrogen of sulfonamide appreciably affects the biological activity of JCC76 derivatives. Replacement of methyl group with hydrogen or hydrophobic alkyl chain $n \mathrm{C}_{6} \mathrm{H}_{13}$ almost abolishes the inhibitory activity. Replacement of methyl group with hydrophilic $\left(\mathrm{CH}_{2}\right)_{2} \mathrm{O}$ $\left(\mathrm{CH}_{2}\right)_{2} \mathrm{OCH}_{3}$ to afford $\mathbf{6 b}$ and results in an about fourfold loss in inhibitory potency. It seems that hydrophilic linker is better than hydrophobic linker. However, it is difficult to further modify the end structure of the hydrophilic linker $\mathbf{6 b}$. Extension of the linear $\mathrm{C}_{6}$ chain with another alky chain or an aromatic ring through for mation of an amide bond restores the biological activity to some extent. Compared to $\mathbf{6} \mathbf{a}$, compound $\mathbf{8 b}$ is about twofold more po tent and compound 8a even exhibits 14 fold more potency. Notice ably, the inhibitory potency of compound $\mathbf{8 a}$ is comparable to that of JCC76, which indicates that the long chain in 8a is well tolerated. A survey of several JCC76 derivatives with different $N$ alkyl chains shows that an appropriate alkyl group can be introduced in lead compound JCC76 without jeopardizing the biological activity.

Based on the information obtained from this preliminary SAR study, we designed and synthesized compound 8c, a novel biotin ylated derivative of JCC76. PyBOP mediated coupling of intermedi ate $7 c$ with biotin efficiently yielded compound $8 \mathbf{c}^{21}$ This compound has a very similar long chain as in compound 8a. Hypo thetically, with this long chain the biotin moiety should protrude for the interaction with streptavidin. The anti proliferation effect of $8 \mathbf{c}$ on SKBR 3 was evaluated and its $\mathrm{IC}_{50}$ value was determined to be $2.21 \pm 0.78 \mu \mathrm{M}$. This biotinylated derivative has comparable cell growth inhibition potency with lead compound JCC76. Biotin did not show any inhibitive activity even at $100 \mu \mathrm{M}$, which further prove that JCC76 was the moiety that cause the anti proliferation activity of the biotinylated probe.

In conclusion, we synthesized a biotin tagged probe of anti proliferative agent JCC76 in this work. The biotin moiety was successfully introduced in the molecule without loss of the biologi cal activity of the parental compound. JCC76 is nonCOX 2 active agent developed based on COX 2 inhibitor nimesulide as a lead compound. It selectively inhibits Her2 over expressed breast cancer cell proliferation, ${ }^{19,20}$ but its specific anti cancer molecular target(s) still remain unclear. There are numerous studies demonstrate that COX inhibitors exhibit anti cancer activity via COX independent mechanism(s). ${ }^{1-5}$ However, it is difficult to elucidate the specific nonCOX targets of these small molecules. Our work can provide a feasible approach for the identification of the new molecular targets of the COX inhibitors. We currently focus on the purification and identification of JCC76 targeted protein(s) by protein pull down and proteomic approach based on the biotin tagged JCC76 probe.

\section{Acknowledgment}

This work was supported by a start up grant from Cleveland State University.

\section{References and notes}

1. Boland, G. P.; Butt, I. S.; Prasad, R.; Knox, W. F.; Bundred, N. J. Br. J. Cancer 2004 $90,423$.

2. Bundred, N. J.; Barnes, N. L Br. J. Cancer 2005, 93(Suppl 1), S10.

3. Clevers, H. N. Engl. J. Med. 2006, 354, 761.

4. Dang, C. T.; Shapiro, C. L.; Hudis, C. A. Oncology (Williston Park) 2002, 16, 30

5. Mazhar, D.; Gillmore, R.; Waxman, J. QJM 2005, 98, 711.

6. Agrawal, A.; Fentiman, I. S. Int. J. Clin. Pract. 2008, 62, 444.

7. Harris, R. E.; Beebe-Donk, J.; Alshafie, G. A. BMC Cancer 2006, 6, 27.

8. Howe, L. R.; Dannenberg, A. J. J. Mammary Gland Biol. Neoplasia 2003, 8, 31.

9. Iwama, T. J. Gastroenterol. 2009, 44(Suppl 19), 72.

10. Rigas, B.; Kashfi, K. J. Pharmacol. Exp. Ther. 2005, 314, 1.

11. Sarkar, F. H.; Adsule, S.; Li, Y.; Padhye, S. Mini Rev. Med. Chem. 2007, 7, 599.

12. Song, X.; Lin, H. P.; Johnson, A. J.; Tseng, P. H.; Yang, Y. T.; Kulp, S. K.; Chen, C. S. J. Natl. Cancer Inst. 2002, 94, 585. 
13. Zhu, J.; Huang, J. W.; Tseng, P. H.; Yang, Y. T.; Fowble, J.; Shiau, C. W.; Shaw, Y. J.; Kulp, S. K.; Chen, C. S. Cancer Res. 2004, 64, 4309.

14. Kawamori, T.; Nakatsugi, S.; Ohta, T.; Sugimura, T.; Wakabayashi, K. Adv. Exp. Med. Biol. 2002, 507, 371.

15. Nakatsugi, S.; Ohta, T.; Kawamori, T.; Mutoh, M.; Tanigawa, T.; Watanabe, K. Sugie, S.; Sugimura, T.; Wakabayashi, K. Jpn. J. Cancer Res. 2000, 91, 886.

16. Shaik, M. S.; Chatterjee, A.; Singh, M. Clin. Cancer Res. 2004, 10, 1521.

17. Tian, G.; Yu, J. P.; Luo, H. S.; Yu, B. P.; Yue, H.; Li, J. Y.; Mei, Q. World J. Gastroenterol. 2002, 8, 483.

18. Su, B.; Darby, M. V.; Brueggemeier, R. W. J. Comb. Chem. 2008, 10, 475.

19. Zhong, B.; Cai, X.; Yi, X.; Zhou, A.; Chen, S.; Su, B. J. Steroid Biochem. Mol. Biol. 2011, 126,10 .

20. Chen, B.; Su, B.; Chen, S. Biochem. Pharmacol. 2009, 77, 1787.

21. Compound 5: White powder, ${ }^{1} \mathrm{H}$ NMR $\left(400 \mathrm{MHz}, \mathrm{CDCl}_{3}\right) \delta 7.970(1 \mathrm{H}, \mathrm{d}$, $J=2 \mathrm{~Hz}), 7.453(1 \mathrm{H}, \mathrm{d}, J=8.4 \mathrm{~Hz}), 7.232(1 \mathrm{H}, \mathrm{s}), 7.126(3 \mathrm{H}, \mathrm{m}), 6.696(1 \mathrm{H}, \mathrm{dd}$, $J=2,8.4 \mathrm{~Hz}), 6.555(1 \mathrm{H}, \mathrm{s}), 5.047(2 \mathrm{H}, \mathrm{s}), 2.834(3 \mathrm{H}, \mathrm{s}), 2.336(3 \mathrm{H}, \mathrm{s}), 2.313(3 \mathrm{H}$, $\mathrm{s}), 2.242(1 \mathrm{H}, \mathrm{tt}, J=3.6,12 \mathrm{~Hz}), 1.245-1.985(10 \mathrm{H}, \mathrm{m})$; Compound 6a: White powder, ${ }^{1} \mathrm{H}$ NMR $\left(400 \mathrm{MHz}, \mathrm{CDCl}_{3}\right) \delta 7.995(1 \mathrm{H}, \mathrm{d}, J=2.4 \mathrm{~Hz}), 7.410(1 \mathrm{H}, \mathrm{s})$, $7.210(1 \mathrm{H}, \mathrm{d}, J=8.4 \mathrm{~Hz}) .7 .094(3 \mathrm{H}, \mathrm{m}), 6.643(1 \mathrm{H}, \mathrm{dd}, J=2.4 .8 .4 \mathrm{~Hz}), 5.036(2 \mathrm{H}$, s), $3.482(2 \mathrm{H}, \mathrm{b}), 2.693(3 \mathrm{H}, \mathrm{s}), 2.317(6 \mathrm{H}, \mathrm{s}), 2.258(1 \mathrm{H}, \mathrm{tt}, J=3.6,12 \mathrm{~Hz}), 1.970-$ $1.174(18 \mathrm{H}, \mathrm{m}), 0.842(3 \mathrm{H}, \mathrm{t}, J=6.8 \mathrm{~Hz})$; Compound $6 \mathbf{b}$ : White powder, ${ }^{1} \mathrm{H}$ $\operatorname{NMR}\left(400 \mathrm{MHz}, \mathrm{CDCl}_{3}\right) \delta 7.902(1 \mathrm{H}, \mathrm{d}, J=2.4 \mathrm{~Hz}), 7.509(1 \mathrm{H}, \mathrm{s}), 7.230(1 \mathrm{H}, \mathrm{d}$, $J=8.4 \mathrm{~Hz}), 7.178(1 \mathrm{H}, \mathrm{s}), 7.091(2 \mathrm{H}, \mathrm{m}), 6.696(1 \mathrm{H}, \mathrm{dd}, J=2.4,8.8 \mathrm{~Hz}), 5.001$ $(2 \mathrm{H}, \mathrm{s}), 3.471(8 \mathrm{H}, \mathrm{m}), 3.338(3 \mathrm{H}, \mathrm{s}), 2.792(3 \mathrm{H}, \mathrm{s}), 2.317(3 \mathrm{H}, \mathrm{s}), 2.311(3 \mathrm{H}, \mathrm{s})$, $2.253(1 \mathrm{H}, \mathrm{tt}, J=3.6,12 \mathrm{~Hz}), 1.956-1.254(10 \mathrm{H}, \mathrm{m})$; Compound 8a: White powder, ${ }^{1} \mathrm{H}$ NMR $\left(400 \mathrm{MHz}, \mathrm{CDCl}_{3}\right) \delta 8.027(1 \mathrm{H}, \mathrm{s}), 7.883(1 \mathrm{H}, \mathrm{s}), 7.134(4 \mathrm{H}, \mathrm{m})$,
$6.686(1 \mathrm{H}, \mathrm{d}, J=8.4 \mathrm{~Hz}), 5.677(1 \mathrm{H}, \mathrm{b}), 5.024(2 \mathrm{H}, \mathrm{s}), 3.487(2 \mathrm{H}, \mathrm{b}), 3.184(2 \mathrm{H}, \mathrm{d}$ $J=6.4 \mathrm{~Hz}), 2.691(3 \mathrm{H}, \mathrm{s}), 2.312(7 \mathrm{H}, \mathrm{m}), 2.178-1.290(26 \mathrm{H}, \mathrm{m}), 0.878(3 \mathrm{H}, \mathrm{t}$, $J=6.8 \mathrm{~Hz})$; Compound 8b: White powder, ${ }^{1} \mathrm{H}$ NMR $\left(400 \mathrm{MHz}, \mathrm{CDCl}_{3}\right) \delta 8.294$ $(1 \mathrm{H}, \mathrm{s}), 8.006(1 \mathrm{H}, \mathrm{s}), 7.854(5 \mathrm{H}, \mathrm{m}), 7.528(2 \mathrm{H}, \mathrm{m}), 7.185(1 \mathrm{H}, \mathrm{d}, J=8.4 \mathrm{~Hz})$, $7.077(3 \mathrm{H}, \mathrm{m}), 6.696(1 \mathrm{H}, \mathrm{dd}, J=2,8.4 \mathrm{~Hz}), 6.589(1 \mathrm{H}, \mathrm{s}), 4.997(2 \mathrm{H}, \mathrm{s}), 3.455$ $(4 \mathrm{H}, \mathrm{m}), 2.680(3 \mathrm{H}, \mathrm{s}), 2.289(7 \mathrm{H}, \mathrm{m}), 1.931-1.192(18 \mathrm{H}, \mathrm{m})$; Compound 8c: White powder, ${ }^{1} \mathrm{H}$ NMR $\left(400 \mathrm{MHz}, \mathrm{CDCl}_{3}\right) \delta 8.201(1 \mathrm{H}, \mathrm{s}), 8.085(1 \mathrm{H}, \mathrm{s}), 7.203$ $(1 \mathrm{H}, \mathrm{d}, J=8.4 \mathrm{~Hz}), 7.101(3 \mathrm{H}, \mathrm{m}), 6.763(1 \mathrm{H}, \mathrm{dd}, J=2,8.4 \mathrm{~Hz}), 6.186(1 \mathrm{H}, \mathrm{s})$, $6.115(1 \mathrm{H}, \mathrm{t}, J=6 \mathrm{~Hz}), 5.223(1 \mathrm{H}, \mathrm{s}), 5.040(2 \mathrm{H}, \mathrm{s}), 4.498(1 \mathrm{H}, \mathrm{m}), 4.314(1 \mathrm{H}, \mathrm{m})$, $3.488(2 \mathrm{H}, \mathrm{m}), 3.149(3 \mathrm{H}, \mathrm{m}), 2.900(1 \mathrm{H}, \mathrm{dd}, J=4.8,128 \mathrm{~Hz}), 2.717(1 \mathrm{H}, \mathrm{d}$, $J=124 \mathrm{~Hz}), 2.684(3 \mathrm{H}, \mathrm{s}), 2.314 \mathrm{7H}, \mathrm{m}), 2.195(2 \mathrm{H}, \mathrm{t}, J=7.2 \mathrm{~Hz}), 1.951-1.283$ $(24 \mathrm{H}, \mathrm{m})$; HRMS calculated for $\mathrm{C}_{39} \mathrm{H}_{58} \mathrm{~N}_{5} \mathrm{O}_{6} \mathrm{~S}_{2}(\mathrm{M}+\mathrm{H})^{+} 756.3828$, found 756.3847.

22. The effect of JCC76 probes on SKBR-3 breast cancer cell viability was assessed by using the 3-(4,5-dimethylthiazol-2-yl)-2,5-diphenyl-2H-tetrazolium bromide assay (MTT) in triplicates. Cells were grown in custom medium in 96-well, flatbottomed plates for $24 \mathrm{~h}$, and were exposed to various concentrations of nimesulide derivatives dissolved in DMSO (final concentration $\leqslant 0.1 \%$ ) in media for $72 \mathrm{~h}$. Controls received DMSO vehicle at a concentration equal to that in drug-treated cells. The medium was removed, replaced by $200 \mu \mathrm{l}$ of $0.5 \mathrm{mg} / \mathrm{ml}$ of 3-(4,5-dimethylthiazol-2-yl)-2,5-diphenyl- $2 \mathrm{H}$-tetrazolium bromide in fresh media, and cells were incubated in the $\mathrm{CO}_{2}$ incubator at $37^{\circ} \mathrm{C}$ for $2 \mathrm{~h}$. Supernatants were removed from the wells, and the reduced 3-(4,5dimethylthiazol-2-yl)-2,5-diphenyl-2H-tetrazolium bromide dye was solubilized in $200 \mu \mathrm{l} /$ well DMSO. Absorbance at $570 \mathrm{~nm}$ was determined on a plate reader. 